\title{
Export Factors Impact Analysis on Textile Industry
}

\author{
Usman Ghani, ${ }^{1}$ Zakia $^{2}$ \\ ${ }^{1}$ Mechanical Engineering Department UET Peshawar, Peshawar, KPK, Pakistan \\ ${ }^{1}$ usmanghani@uetpeshawar.edu.pk \\ ${ }^{2}$ Air University Islamabad, Peshawar, KPK, Pakistan \\ 2ugkme@yahoo.vom
}

\begin{abstract}
Textile industry contributes 57\% percent of total export volumes and $8.5 \%$ of the GDP of Pakistan. Government also extended export package and preferential interest rates for working capital exigencies and capital expenditures related to the industry but target never achieved. Though textile policy has aggressive targets but it seems that the policy makers failed to address the real problem that eventually resulted failure of achieving it. On the contrary present government aggressively devaluated the local currency by not taking more loans for controlling exchange rate artificially. This resulted Pakistani exportable products cheaper in international market which attracted future orders in return. But on the other hand, interest rates increased almost double which increased finance cost accordingly. Due to massive devaluation, cost of producing energy increased together with cost of spare parts for maintenance and dyeing chemical for value added products. Therefore, this research is focused to see the impact of factors that could affect the exports either way positive or negative.
\end{abstract}

Keywords: Exports, Textile Industry, GDP, Factors

\section{INTRODUCTION}

Agriculture sector is considered to be the bake bone in exports of Pakistan. Pakistan geographical boundaries, its environment and fertile land make it very suitable for agriculture sector that is why their exports mainly consist of agriculture products. The main export items of Pakistan are rice, furniture, cotton fiber, leather etc. (Textile vision 2005). In terms of export clusters, Pakistan's economy is mostly concentrated in textile \& apparel, leather goods, agricultural products, construction material, logistics, row cotton, fish and sports good. Out of which textile $\&$ apparel, are the biggest and the fastest growing clusters (Belaya Hussain 2011). The fertile land of Pakistan and its conducive environment for cultivation of cotton crop has a great impact on the textile production and its use in Pakistan and in the world. Export of textile product is one of the main sources of foreign remittance for Pakistan and contributes disproportionally to the total export of Pakistan. To cover the emerging demand of textile, the textile industry in Pakistan has changed manifold over the years from simple to designs painted, dyed, embroidery and high-quality woven silk that was market competitive like that of China.

Pakistan textile industry is neither totally locally demand oriented nor its development totally dependent on outside market. Historically, due to the region's significant position in the east-west sea trade route, the cotton from indoPak and silk from china was present here. These products were accepted in substitute for the region pepper, spices and jungle reserves. In since cases these textile imports temporarily disturbed local production because the imports were so cheaper that it made economic sense for locals to buy the imported clothing materials rather than create their own. Being part of the international route, it had an immense influence on international consumers but the regional industry was never completely displaced. This exodus of foreign products in the market compelled the local industry once again gained competitive hand. The fertile land of Pakistan accompanied with the technological advancement in cotton cultivation, can produce a very high-quality cotton crop. However, there are large numbers of countries in the competition of textile export specially countries of the Asian continent with similar land and weather condition. So, economists have a deep interest in determining the factors that can influence exports of textile goods in order to differentiate their cotton products in the international market.

Pakistan textile industry relies on local agriculture to supply its raw materials; thus, the success of the cotton crop is significant to the growth of the textile industry. Cotton makes up for 14 percent of land which is enable for cultivation. Textile industry is playing a central role in the total exports volume of Pakistan. Since petition (1947) there has been an impressive rise in cotton production and expansion of textile industry. Form 1947 till 2012 cotton bales raised from 1.2 million to 11 million bales, mills unites showed an increase from 4 to 610 and spindles units from 177,000 to eight hundred and five million, looms and finishing units also has shown rise but not in the same scale. This sector has 38 percent of labor force employed and accounts for $61 \%$ share in total exports. 
Pakistan is the 8th largest exporter of textile products in Asia. This sector contributes 9.5\% to GDP and provides of employment to about 15 million people or roughly $30 \%$ of the total workforce of the country. Pakistan is the $4^{\text {th }}$ largest producer of cotton with the third largest spinning capacity in Asia after China and India, and contributes $5 \%$ to the global spinning capacity. The growth rate of world textile is $2.5 \%$ in which Pakistan's contribution is $1 \%$. Pakistan is formerly the lead producer of cotton world widely; the priority area towards industrialization is the expansion of textile products there are1,221 ginning units, 442 spinning units, 124 large spinning units and 425 small units which produce textile products. Various sectors comprising the value chain are SPINNING; it mostly operates with house weaving, dyeing and finishing services. Small and medium sized companies comprise the WEAVING; only part of the processing sector, which comprise of dyeing pointing and finishing subsectors, while other operates as small and medium sized units. Overall processing industry is dominated by the printing segment filled by textile dyeing and fabric bleaching. The highest employment within the textile value chain is occupied by garments manufacturing segments.

Pakistan's textile industry depends on domestic agriculture to supply its raw materials; thus the success of cotton crop is crucial to the health of the textile. Cotton accounts for 14 percent of land under cultivate. In Asia Pakistan ranks as the 8th leading exporter of textile goods. It contributes up to $8.5 \%$ to the total GDP of Pakistan. It vies opportunities to about 15.5 million people, which is $38 \%$ of the country work force. As Pakistan has major stress on agro-based industries so now it is giving highest priory to industrialization. Being one of the largest cotton producers in the world, Pakistan textile industry is now trying to make complete use of its rich resources and for industrialization purpose textile industry has been taken on priority levels.

These findings suggest that policy makers in Pakistan should consider both the existence and degree for exchange rate instability and notice the same impact of exchange rate instability on each sector of macroeconomic in implementation of policies so that higher volumes of trade and foreign direct investment may be attracted.

\section{LITERATURE REVIEW}

Different studies have been done for estimating export functions for different sectors generally considering profitmaximizing firms (Arize A.C. 1999, smith C.E. 1999). With the obvious price and scale measure the literature has currently taken an additional variable of exchange rate volatility (Pozo, 1992, McKenzie,1999). An ambiguous policy impact had been shown by this variable as if the level of exchange rate volatility would suggest the policies to stabilize the exchange rates in order to bring gains in export. Conversely literature also indicates that exchange rate variability is beneficiary of export purpose since the devaluation of local currency (PKP) against dollars creates an opportunity for competitive pricing of the product/services.

The standard equation used for international trade and which incorporate exchange rate variability was obtained but Hooper and Kohlhagen for the first time and still this form has been used as the theoretical basis for the research word in this course. The argument was "higher exchange-rate volatility leads to higher cost for riskaverse traders and to less foreign trade. This is because the exhale rate is agreed on at the time of the trade contract, but rates become unpredictable this uncertainty about the profits to be made and, hence, reduces the benefits of international trade".

As pre Hooper and Kohlhagan, the total output and its prices of goods in the export situation is as following:

$\mathrm{Q}=\left(\mathrm{a} . \mathrm{UC}+\mathrm{b} . \mathrm{PD}+\mathrm{c} . \mathrm{Y}\right.$ d. $\mathrm{CU}+\mathrm{a}_{\mathrm{i}}^{2} / 2 \mathrm{p}^{*}\left[\mathrm{EH}+\mathrm{rb}(1-\mathrm{a}) \mathrm{oR}_{\mathrm{i}}\right]$

Where $\mathrm{a}<0, \mathrm{Q}$ is the total output, $\mathrm{UC}$ is the unit cost of production, $\mathrm{CU}$ in non- Pricing rationing fi own output $\mathrm{PD}$ is the prices of other goods and $\mathrm{Y}$ is income in the domestic country. The function indicates that a raise in the cost of production\& foreign exchange $\left(H\right.$, or its components Banda) or an increase in the variability $R_{i}\left(o R_{i}\right.$, the standard deviation) will transfer the demand for import to the opposite side. The equation was criticized due to the risk aversion of trade $(r>0)$. Trade is negatively affected by an increase in exchange rate variability (oRi). As Newbery and Stieglitz [1981], Coes [1981], and Gravwe [1988] pointed out; this result follows because of the implicit assumption \& constant absolute risk aversion of traders. This theory efficiently eliminates the income effect of a change in exchange variability. The so-called traditional variables which are income and relative prices are taken as the main factors of exports and imports demand. In many cases it is proved that trade is positively associated with inner and outer foreign investment. (M, Canmaeor and C Tamari 2004].

The export promotion policies such as subsidies, transport facilities and tax concessions should be encouraged. If relative price elasticity is between minus 1 and minus 1.4 than it will shows that exports are competitive in the international makes and these countries have the option on devalue are currency to improve export earnings (S. Kumar 2011). Some economists have proposed the currency devaluation as an important factor of export function (Schuh. 1974). Another study related to export for agriculture sector was done by Hussain (2006), who showed the export performance of Bangladesh fisheries sector by considering different variables. He founded the impact for above variables on total quantity of fish exported from Bangladesh. Result shows that the model fits very well. All explanatory variables except exchange rate show expected signs and are found highly significant at $1 \%$ level. Piet Sercu\& Raman Uppal (2003) came up with results that exchange-rate volatilely shows a turn down in trade. 
As compare to the previous work, done on exchange rate volatility and their impact on trade, in this model exchange rates were found out each other due to exogenous variability.

Rana Ijaz (2010) attempted to classify the variables affecting the production and export productivity of cottage industry of Sialkot. He came up with the conclusion that the working experience of Entrepreneur, working environment in CIU education and distance from market affects the production and export productivity of cottage industry. Capital and educated labor have positive impact on total production of cottage capital and industrial unit. He gives justification with his results that may be cottage industrial an extra have an extra concern with labor that is why the elasticity of production with respect to labors very high. It may be concluded that production in total production in CIUs is labor intensive and an increase in working house may leads to an increase in total production of unis which with automatically boost up the export productivity. Increasing of capital also has positive impact on the total production of unit.

According to Rao and Singh (2007) many empirical studies on export demand are biased due to exclusion of exchange rate in the relative price variable. Exports with be more competitive in the international market with higher price elastically and there will be a real devaluation to improve rate fluctuations on trade balance. Arize (2001) have found a long run and stable relationship between export and the factors which determine. Guise and Cancel (2002) found export demand function by taking the supply side determinants such as domestic private consumption, gross domestic product human capital foreign and relative export prices. In a study done by lqbal and Ehsanullah (2011) impact of exchange rate volatility on macrocosmic variables has been analyzed through application of regression techniques. Results show the presence of posit impact exchange rate volatile on GDP, trade openness and growth rate, while negative impact of exchange rate volatility on foreign direct investment was found.

In literature every study was related to different sectors and countries, impact of different variables was shown on total export. Fayyaz Hussain (2007) have estimated export demand function with three variables for Pakistan and have done a disaggregate analysis while taking nine main sectors in account which includes textile industry as well. Fayyaz Hussain (2007) has taken textile industry as a whole and different sector were not concerned by him. So there is a need to estimate export function with more variables like exchange rate volatility and GDP and to show the impact of these variables on different steers of textile industry.

\section{PROBLEM STATEMENT}

There is a little research work which show a linear model among total textile price of export item in domestic country, their export prices, exchange rate, exchange rate volatility and GDP of developing country. Most of the research works on above stated variables and their relationship has been done in developed countries and very slight evidence available from developing countries, but they are related to a narrow sector like carpet industry. There is a need to know the relationship among these variables in a linear way to help economists in improving the efficiency of their export and add research evidence to the body of knowledge from developing countries like Pakistan.

\section{RESEARCH OBJECTIVE}

Total export for a country depends on number of factors like price of export items, exchange rate, exchange rate volatitly and GDP of the country etc. However, study regarding association or link between these variables for any specific industry like textile industry has not been done yet. There is a need to develop this relation especially in the context of textile industry as its contribution to the total GDP is $8.5 \%$. Therefore, the objectives of the research are:

- To estimate an export function and its application on three main sectors of textile industry i.e. cotton, yarn and cloths which collectively contribute up to $55 \%$ of total textile exports of Pakistan.

- To see the impact of different variables on export of different sectors of textile industry.

- To evaluate the effects of different economic variable on the textile industry of Pakistan and total textile exports.

- To see the effects of economic variables like currency exchange rate fluctuations, GDP of domestic country, relative prices (export prices/domestic prices), total production and time trend.

1. Research Questions

The proposed research will address the following research questions:

- What is the relationship between textile export and the PKR exchange rate?

- What is the relationship between GDP of Pakistan and textile export volume?

- Is there any impart of total production on total relative prices?

- What is the relationship between textile export volume and relative prices? 
- Can a structural model be built to indicate the relationship between export volumes, price, GDP exchange rate and relative prices?

\section{THE ORETICAL FRAMEWORK AND METHODOLOGY}

A lot of study has been done on textile industry of Pakistan. However, in most of studies, textile industry was taken as a whole. Being a major contributor to total exports its main sectors should be studied individually. Yearly data of three main textile sector is taken that have major contribution in textile exports. The three sectors are cloth, yarn and cotton. Theoretical framework and the methodology used for testing of the model is shown in figure. 1 while various study variables are shown in table 1.

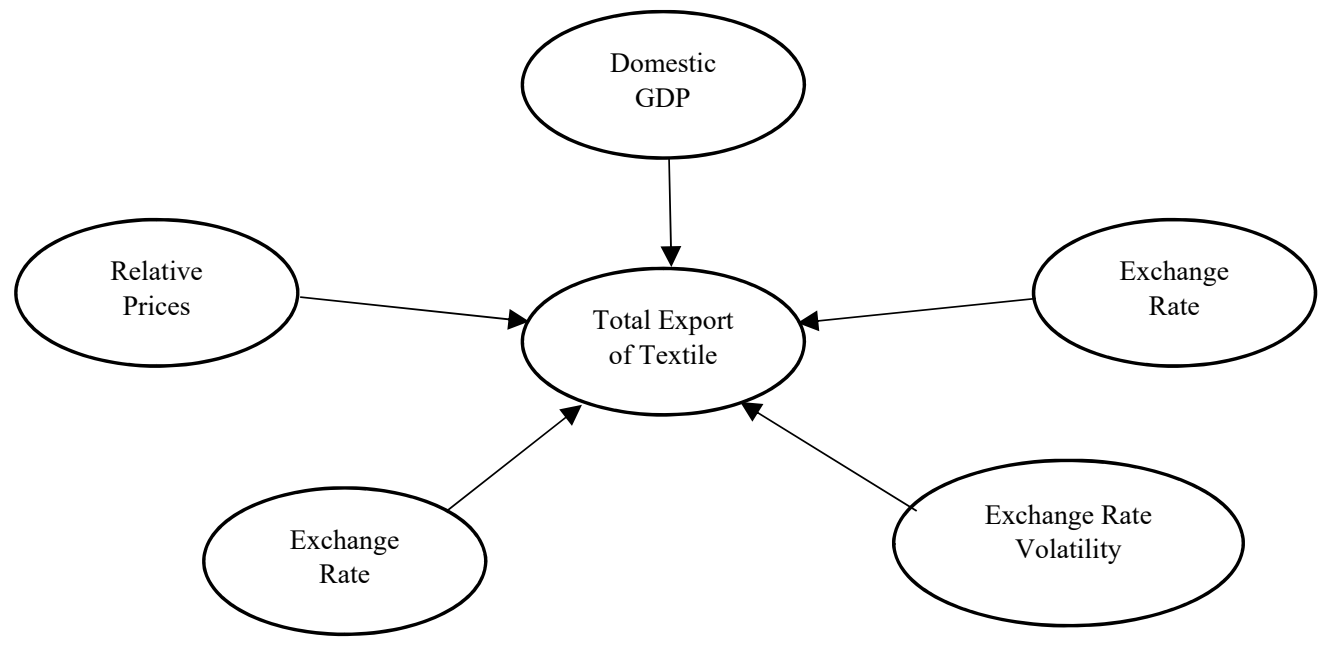

Fig.1 Theoretical framework and the methodology for model testing.

TABLE I. Various variables of the study are as follows

\begin{tabular}{lll}
\hline Dependent variable & Independent variables & Moderation variables \\
\hline Total export of textile industry of & Export prices of sector. & Time trend. \\
Pakistan & GDP of domestic country. & Nature of trade agreements \\
& Domestic prices of sector. & between domestic and foreign \\
& Exchange rate volatility. & countries. \\
& Total production of textile. & \\
\hline
\end{tabular}

\section{Export Prices of Textile Sector}

Exports pricing is different from that of export counting. The price we offer to the customer (importer) is called export price. Cost is the expenditure that we pay/incur for buying or in making of product. Export pike includes profit margin and cost (expenditure). The mainly key device for increasing sales and facing market competition is the export pricing. All export benefits and expenditures should be taken into account while concerning export prices of textile goods. Export piecing strategies depends on different environmental situation.

\section{GDP OF DOMESTIC COUNTRY}

Gross domestic production (GDP) is the advertise value of all final goods and services formed inside the boundaries of country in a specified time period. It is equal to total consumer, investor and government expenditure, in addition with exports value minus imports value. GDP per capita it is offer considered as an indicator of a country standard of living. Sometimes GDP per capita has been taken as a measure of personal income. GDP is considered to have a positive impact on total exports. It means with better GDP total textile exports will increase.

\section{Domestic Prices of Textile Products:}

Domestic prices are those prices which are offered in domestic country (in the boundaries). These prices should be low than export. It is equal cost of raw material, capital, and labor plus packaging cost and low profit margin. We are taking relative prices export/domestic pikes which have no positive or negative or negative impact on total exports. 


\section{Exchange Rate in Domestic Country}

Currency exchange rate (foreign-exchange rate, forex of rate) is the price of one currency in terms of other currency. The currency of one nation is exchanged with other nation's currency in order to facilitate foreign trade, export and import. Every country manages the value of its currency by using different mechanisms. As part of this function, it determines the exchange rate regime that will apply to its currency.

\section{DATA COLLECTION AND METHODOLOGY}

Data is taken from 1917 to 2012 from Pakistan textile statistics. This data includes the export of textile sector per year, domestic and export price, exchange rate in domestic country, exchange rate volatility, total production and GDP per year.

\section{Model Development}

There are a number of empirical studies about export functions mainly based on the notion of specialized profitmaximizing firms (Arie A.C.1999, barman, et al 1992, smith C.E. 1992). Here it has included the obvious and scale measures (GDP and unit price measures) but recently an additional factor has been brought, which is exchange rate (De grouse, 1988, tours by and Thorsby 1987, Pozo 1992, McKenzie, 1999). There is an obvious policy interest in this variable because a negative coefficient would suggest that a stable exchange rate can bring gains in trade volume even if there is a direct relationship between exports and the level of exchange rates. A number of models have been planned signifying that exchange rate variability might adversely affect export volume. (barkoulas, 2002; grouse 1988). On the other hand, the literature also give many reasons for positive impact of exchange rate verbally on export trade. So far as the export for agriculture sector is concerned there is an empirical work done by karma (2003) who has estimated export function for Iran union carpet and pistachio sectors over 1970-1998. His export function is given in the following form:

$\log \mathrm{Xs}=\mathrm{b} 0+\mathrm{b} 1 \log (\mathrm{PX} .(\mathrm{Pb} . \mathrm{Er})+\mathrm{b} 2 \log (\mathrm{X}-1)+\mathrm{b} 3 \log \mathrm{YR}+\mathrm{n} \mathrm{B} 4 \log \mathrm{SST}+\mathrm{b} 5 \mathrm{~T}$.

Where $\mathrm{Xs}=$ real export volume. $\mathrm{Pb}=$ domestic price, $\mathrm{Px}=$ export price, $\mathrm{ER}=$ exchange rate in procedure country in dollar, $\mathrm{YR}=$ procedure of selective output in the country (total production), $\mathrm{SSR}=$ Supply Side Shock and T= Time trend. In this paper those concepts and measurements will be followed, which are accepted by different researchers and leads to an equation of the form and also used by for estimating export function for carpet industry of Pakistan.

$\log X_{t}=a 0+a_{1} \log Y_{t}+a_{2} \log P R t+a_{3} \operatorname{logFRt}+a_{4} \log E V t+a_{5} \log Q t i+U_{t}$

Where $\mathrm{Xt}$ is the total export of Textile sector of textile industry, $\mathrm{Y}_{t}$ is GDP of domestic country, $\mathrm{PR}_{\mathrm{t}}$ is relative prices of Textile sector (export price /domestic price), $\mathrm{ER}_{t}$ exchange rate in domestic country, $\mathrm{EV}_{\mathrm{t}}$ is exchange rate volatility and $\mathrm{Qt}_{\mathrm{i}}$ is the total production of Textile sector.

The domestic production $\left(\mathrm{Qt}_{\mathrm{i}}\right)$ is expected to have a positive sign as higher production results in higher exportable surplus. On a priority basis, a direct relationship is expected between quantity exported of a commodity (Xt) and Gross Domestic Production (Yt), a reflection of robustness of the economy. The exchange rate (ERt) plays a crucial role in explaining the variations in net exports of a commodity especially in a country where exchange rates are volatile. Thus a positive sign is anticipated between the exchange rate and exports. According to economic theory relative prices (PRt) have no impact on total export $(\mathrm{Xt})$ and exchange rate volatility $(\mathrm{EVt})$ has negative impact on export.

\section{Regression Analysis}

Statistical methods used are estimated Least Square and Polled Least Square regression analysis, to measure the relationship of two variable or we predict the value of dependent variable on the basis of independent variable. Method of measuring relationship between two variables is through the variation of dependent variable due to variation in independent variables. Regression result cannot find the cause and effect relationship of variables without the support of theory regarding that issue (Keller \& Warrakc, 2003).

In this study, initially we used the augmented dickey fuller test to check that each variable is unit root or not. There are some variables which are not unit root then we find their first difference which is unit root. Then we check the model for autocorrelation through Breusch-Godfrey Serial Correlation LM Test. As our model suffer from autocorrelation or order one and other two so we modify our model for further regression. Modified model is also tested for heteroskedasticity through OLS method. The results of this test were found to be appropriate as compared to the OLS method of estimation. OLS method shows the variability and does not make use of the information contained in the unequal variability of dependent variable. 


\section{RESULT AND DISCUSSION}

Textile industry is a major industry in Pakistan which provides employment to 30\% work force of Pakistan and plays a vital role in the total exports. There was a need to study this industry individually and find different variables which affects its exports. According to the objective of study, the export function for textile industry of Pakistan is estimated and find out the impact of different variables on total export volume. For this purpose, yearly data from 1971 to 2010 of three main textile sectors has been taken that are yarn, cloth and cotton. Before applying regression, all variables were checked for unit root through augmented dickey fuller test with least square method. All variables include exchange rate, exchange rate volatility, GDP, total production, relative prices (export prices/domestic prices) except total export are unit root and can be used for regression.

\section{Regression}

In this study the impact of different variables on export volume of cotton, yarn and clothes have been examined in the given model exp (total export) is dependent variable whereas EX-rate. Ex rate volatility. GDP, total production and REL prices are independent variables. All variables are market-based measure except relative prices which is accounting base measure.

In the start we have tested our equation for unit root test through Augmented Dickey-Fuller test and found that all the variables are unit root except exchange rate. To make it unit root we will take its first difference which is unit root. After this test we have modified our equation which is in the given form.

TEXP $=0.0002339615005 *$ EX_RATE -() $.0009906669406 * E X R A T E \_V O L+2.30492082 \mathrm{e}-006 *$ GDP I $0.04387321762 *$ PRODUCTION $+1.315036388 \mathrm{e}-005 *$ REL PRICE

From this equation it can be stated that exchange rate (EX-RATE) have a positive and exchange rate volatility have negative impact on total exports. Positive signs of GDP and production show positive relation with total exports. The coefficient of relative prices is unpredictable from the given equation.

\section{Test for Autocorrelation}

$\mathrm{H}_{0}$ : No autocorrelation

$\mathrm{H}_{1}$ : there is autocorrelation.

TABLE 2. Breusch-Godfrey serial correlation LM test.

\begin{tabular}{cccc}
\hline F-Statistics & $\mathbf{4 . 3 3 1 5 2 6}$ & Probability & $\mathbf{0 0 2 1 6 3 7}$ \\
\hline Obs* R-suqared & 8.307885 & Probability & 0.015702 \\
\hline
\end{tabular}

Test Equation:

Dependent variable: RESID

Method: least Squares

Resample missing value lagged residuals set to zero.

TABLE 3. Least squares method test.

\begin{tabular}{ccccc}
\hline Variable & Coefficient & Std - Error & t-Statistics & Prob \\
\hline EX_RATE & 0.000143 & 0.001068 & 0.134016 & 0.8942 \\
\hline EXRATE_VOL & 0.000117 & 0.002125 & 0.054946 & 0.9565 \\
\hline GDP & $-6.89 \mathrm{E}-07$ & $1.21 \mathrm{E}-06$ & -0.569578 & 0.5729 \\
\hline PRODUCTION & 0.027035 & 0.038397 & 0.704084 & 0.4865 \\
\hline REL_PRICE & $-5.36 \mathrm{E}-06$ & $4.51 \mathrm{E}-06$ & -0.118857 & 0.9061 \\
\hline RESID (-1) & 0.336946 & 0.183885 & 1.832371 & 0.0762 \\
\hline RESID (-2) & 0.486821 & 0.195884 & -2.485247 & 0.0184 \\
\hline
\end{tabular}

TABLE 4. R-squared test.

\begin{tabular}{cccc}
\hline R-squared & $\mathbf{0 . 2 1 3 0 2 3}$ & Mean dependent var & $\mathbf{- 9 . 1 0 E - 0 7}$ \\
\hline Adjusted R-Squared & 0.065464 & S.D. dependent var & 0.000174 \\
\hline S.E. of regression & 0.000168 & Akaike info criterion & -14.38258 \\
\hline Sum suqared resid & $9.05 \mathrm{E}-07$ & Schwarz criterion & -14.08400 \\
\hline Log likelihood & 287.4604 & Durbin - Watson stat & 1.906142 \\
\hline
\end{tabular}


Obs*R-squared (8.308) > Chi-square (02) i.e. 5.991, therefore it can be concluded that the series suffers from autocorrelation of order one. If $\mathrm{p}_{\text {_value }}>.10$, which shows insignificancy. If $\mathrm{p}$ _value $<10$, i.e. .01, .5, it means it is significant. Value of R-square is 21 which shows that independent variables have $21 \%$ variation in dependent variable. After these statistics p_val $(.02<1)$ shows significant results. It leads to the rejection of null hypothesis; therefore, it can be concluded that the series suffers from autocorrelation or order one.

Test Equation:

Dependent Variable: RESID

Method: Least Squares

TABLE 5. Breusch - Godfrey serial correlation LM test.

\begin{tabular}{cccc}
\hline F-Statistics & $\mathbf{2 . 8 5 1 3 2 2}$ & Probability & $\mathbf{0 . 5 3 3 0 5}$ \\
\hline Obs* R-suqared & 8.433305 & Probability & 0.037856 \\
\hline
\end{tabular}

Obs*R-squared $(8.433)>$ Chi-square $(03)$ i.e. 7.815 , therefore it can be concluded that the series suffers from autocorrelation of order two.

\section{Modified Regression}

As our model was suffering from autocorrelation of order one and order two so we have to modify our equation. After adjustment of equation our model becomes as given:

$\mathrm{TEXP}=0.0002385180382 *$ EX RATE $-0.0002714493121 *$ EXRATE_VOL $+1.80592014 \mathrm{e}-006 *$ GDP $0.03279418804 *$ PRODUCTION $-6.538992835 \mathrm{e}-006 * \mathrm{REL}$ PRICE $+[\mathrm{AR}(1)=03.3536434364, \mathrm{AR}(2)=-$ $0.4665358898]$

\subsection{Test for Autocorrelation}

$\mathrm{H}_{0}=$ There is no autocorrelation

$\mathrm{H}_{1}=$ Autocorrelation exists

TABLE 6. Breusch - Godfrey serial correlation LM test.

\begin{tabular}{cccc}
\hline F-Statistics & $\mathbf{1 . 0 5 3 5 1 2}$ & Probability & $\mathbf{0 . 3 6 2 1 2 9}$ \\
\hline Obs* R-suqared & 2.587712 & Probability & 0.274211
\end{tabular}

A collection of random variables is called heteroskedastic if a subpopulation has different variances from others. So the absence of homoscedasticity is hetroskedasticity. The existence of hetroskedasticity is a major concern in regression analysis application, including the analysis of variance, because it can give invalid statistical tests of significance. It assumes that modeling errors are normally distributed and that their variance do not vary with the effects being modeled. For this purpose, we test our model for heteroskedasticity through white test.

\subsection{Test for Heteroskedasticity}

$\mathrm{H}_{0}$ : There is no heteroskedasticity

$\mathrm{H}_{1}$ : heteroskedasticity exists

TABLE 7. White Heteroskedasticity test.

\begin{tabular}{cccc}
\hline F-Statistics & $\mathbf{2 . 8 4 1 1 1 0}$ & Probability & $\mathbf{0 . 5 7 5 6}$ \\
\hline Obs* R-suqared & 19.31978 & Probability & 0.036384 \\
\hline
\end{tabular}

Test Equation:

Dependent: Least Squares

P_value in both statistics are greater than .10, which shows insignificancy, it leads to the acceptance of null hypothesis. Our modified regression has neither autocorrelation nor heteroskedasticity and therefore the model is fit to draw inference from OLS estimator.

\section{Hypothesis}

$\mathrm{H}_{0}$ : Export volume of textile sector is not related with gross domestic production of a country.

$\mathrm{H}_{1}$ : Export volume of textile sector is positively related with the gross domestic production of a country.

Short Run

DEXP $=-0.0006811502431 *$ EX_RATE $-0.0007908201165^{*}$ EXRATE_VOL $+1.101136561 \mathrm{e}-005 *$ GDP $0.555790746 *$ PRODUCTION $+4.6323448131 \mathrm{e}-005 *$ REL_PRICE $+4.917727755 \mathrm{e}-006 *$ GDP $(-1)+$ $5.981930899 \mathrm{e}-006 * \mathrm{GDP}(2)+0.6985994201 * \mathrm{RESID} 01+[\mathrm{AR}(1)=0.005539490867, \mathrm{AR}(2)=-0.6109368168]$

Equation: United 
TABLE 8. Wald test.

\begin{tabular}{cccc}
\hline Test Statistic & Value & df & Probability \\
\hline F-Statistics & 5.202768 & $(3,23)$ & 0.0069 \\
\hline Chiq-square & 15.60830 & 3 & 0.0014 \\
\hline
\end{tabular}

C.V $=5.20>\mathrm{F}(3,23)$ i.e. 3.05 and $\mathrm{p}$ value $(.0069<.10)$ shows significant results which leads to the rejection of null hypothesis and means GDP impact upon yarn export in the short run (in short run results are calculated by taking difference of certain variables). Same results were found for cotton and cloths sectors of textile industry. As GDP have positive impact on three major sectors of textile industry, it shows that GDP have positive impact on overall textile industry of Pakistan.

Long Run:

DEXT $=-0.0006491205741 *$ EX_RATE $+7.72836401 \mathrm{e}-005 *$ EXRATE_VOL $+1.050648139 \mathrm{e}-005 *$ GDP $0.003681188531 *$ PRODUCTION $+4.864057725 \mathrm{e}-005 *$ REL_PRICE + 5.627687899e-007*GDP (-1) + $3.17876706 \mathrm{e}-006 * \mathrm{GDP} \quad(-2)+2.321818294 \mathrm{e}-006 * \mathrm{GDP} \quad(2)+3.151414761 \mathrm{e}-006 * \mathrm{GDP}(-3)+$ $0.7083649487 *$ RESID0 $1+[$ AR $(1)=0.09321976865$, AR $(2)=-0.6368470433]$

Equation: United

TABLE 8. Wald test.

\begin{tabular}{cccc}
\hline Test Statistic & Value & df & Probability \\
\hline F-Statistics & 5.230176 & $(3,20)$ & 0.0268 \\
\hline Chiq-square & 16.15088 & 5 & 0.00064 \\
\hline
\end{tabular}

5. Null Hypothesis Summary

TABLE 9. Null hypothesis test

\begin{tabular}{ccc}
\hline Normalized Restriction (=0) & Value & Std. Err \\
\hline $\mathbf{C ~ ( 3 )}$ & $-1.05 \mathrm{E}-05$ & $5.12 \mathrm{E}-06$ \\
\hline $\mathbf{C ~ ( 6 )}$ & $5.63 \mathrm{E}-07$ & $4.95 \mathrm{E}-06$ \\
\hline $\mathbf{C ~ ( 7 )}$ & $3.18 \mathrm{E}-06$ & $4.60 \mathrm{E}-06$ \\
\hline $\mathbf{C ~ ( 8 )}$ & $2.32 \mathrm{E}-06$ & $4.36 \mathrm{E}-06$ \\
\hline $\mathbf{C ~ ( 9 )}$ & $3.15 \mathrm{E}-07$ & $2.35 \mathrm{E}-06$ \\
\hline
\end{tabular}

C.V $=5.20>\mathrm{F}(3,20)$ i.e. 2.60 and p_value $(.0268<.1)$ shows significant results so the null hypothesis and means GDP impact upon yarn export in the long run (in long run results are calculated by taking difference of certain variables) and whole textile industry as well.

$\mathrm{H}_{0}$ : Export volume of Textile sector is not associated with relative price.

$\mathrm{H}_{1}$; Export volume of Textile sector is negatively associated with export price.

Short Run

Equation: United

TABLE 10. Wald test.

\begin{tabular}{cccc}
\hline Test Statistic & Value & df & Probability \\
\hline F-Statistics & 0.223134 & $(3,23)$ & 0.8793 \\
\hline Chiq-square & 14.669401 & 3 & 0.0804 \\
\hline
\end{tabular}

6. Null Hypothesis Summary

TABLE 11. Null hypothesis test.

\begin{tabular}{ccc}
\hline Normalized Restriction $\mathbf{( = 0 )}$ & Value & Std. Err \\
\hline $\mathbf{C ~ ( 5 )}$ & $7.28 \mathrm{E}-06$ & $3.59 \mathrm{E}-05$ \\
\hline $\mathbf{C ~ ( 6 )}$ & $8.71 \mathrm{E}-06$ & $3.36 \mathrm{E}-05$ \\
\hline $\mathbf{C ~ ( 7 )}$ & $7.48 \mathrm{E}-06$ & $3.25 \mathrm{E}-05$ \\
\hline
\end{tabular}


C.V $=0.223>\mathrm{F}(3,23)$ i.e. 3.05 and p_value $(.8793<.10)$ also supports the acceptance of the null hypothesis, it means relative prices (export price / domestic price) does not impact upon yarn export in the short sun. Same results were found for other two sectors which are cotton and clothes. So it can be concluded that the increase or decrease in relative prices have no impact on export of whole textile industry. The result is same it was expected it means our results support the existing literature.

$\mathrm{H}_{0}$ : Exchange rate has not impact on exports volume

$\mathrm{H}_{1}$; Exchange rate has negative impact on export volume

Short Run

Equation: United

TABLE 12. Wald test.

\begin{tabular}{cccc}
\hline Test Statistic & Value & df & Probability \\
\hline F-Statistics & 0.180663 & $(2,23)$ & 0.9084 \\
\hline Chiq-square & 14.541989 & 3 & 0.0096 \\
\hline
\end{tabular}

\section{7. $\quad$ Null Hypothesis Summary}

TABLE 13. Null hypothesis test.

\begin{tabular}{ccc}
\hline Normalized Restriction (=0) & Value & Std. Err \\
\hline C (6) & 0.001857 & 0.004484 \\
\hline C (6) & -0.002351 & 0.003752 \\
\hline C (7) & 0.000324 & 0.002055 \\
\hline
\end{tabular}

$\mathrm{C} . \mathrm{V}=.180<2,23$ and $\mathrm{p}$ _value $.9084>$.10) which suppose to the acceptance of the null hypothesis. So, exchange rate has no impact on textile industry in short and long run as well. In some studies, negative impact of exchange rate was shows on export volume. But according to our analysis there is no impact. Likely results were found out for the other sectors.

$\mathrm{H}_{0}$ : Export volume of Textile sector is not associated with exchange rate volatility

$\mathrm{H}_{1}$; Export volume of Textile sector has negatively relationship with exchange rate volatility.

Short Run

Equation: United

TABLE 14. Wald test.

\begin{tabular}{cccc}
\hline Test Statistic & Value & df & Probability \\
\hline F-Statistics & 03.9210732 & $(3,23)$ & 0.09607 \\
\hline Chiq-square & 0.291819 & 3 & 0.9616 \\
\hline
\end{tabular}

In short run $\mathrm{C} . \mathrm{V}=03.921>3.23$ and $\mathrm{p}_{-}$value $.096<0.1$, justify the rejection of the null hypothesis. Exchange rate volatility shows 95 percent variation in dependent variable. The results are same as they were expected. Same results for all three sectors suppose that exchange rate volatility has negative impact on textile export volume.

Long Run

Equation: United

TABLE 15. Wald test.

\begin{tabular}{cccc}
\hline Test Statistic & Value & df & Probability \\
\hline F-Statistics & 0.717367 & $(5,20)$ & 0.6179 \\
\hline Chiq-square & 3.586833 & 5 & 0.6103 \\
\hline
\end{tabular}




\section{Null Hypothesis Summary}

TABLE 16. Null hypothesis test.

\begin{tabular}{ccc}
\hline Normalized Restriction (=0) & Value & Std. Err \\
\hline C (2) & 0.000365 & 0.006591 \\
\hline C (6) & 0.002142 & 0.006885 \\
\hline C (7) & -0.010879 & 0.006594 \\
\hline C (8) & -0.006062 & 0.006375 \\
\hline C (9) & 0.002768 & 0.006660 \\
\hline
\end{tabular}

Results shows that exchange rate volatility have a negative impact on export volume of textile industry in short run and in long run.

$\mathrm{H}_{0}$ : Export volume of Textile sector is not associated with total production of textile sector

$\mathrm{H}_{1}$; Export volume of Textile sector is positively associated with total production of textile sector.

Short Run

Equation: United

TABLE 17. Wald test.

\begin{tabular}{cccc}
\hline Test Statistic & Value & df & Probability \\
\hline F-Statistics & 4.619475 & $(3,23)$ & 0.0114 \\
\hline Chiq-square & 13.85842 & 3 & 0.0031 \\
\hline
\end{tabular}

8. Null Hypothesis Summary

TABLE 18. Null hypothesis test.

\begin{tabular}{ccc}
\hline Normalized Restriction (=0) & Value & Std. Err \\
\hline C (4) & 0.047321 & 0.029991 \\
\hline C (6) & -0.090383 & 0.033130 \\
\hline C (7) & -4.045509 & 0.018757 \\
\hline
\end{tabular}

C.V $4.62>3.23$ and p-value $.01<.10$, so null hypothesis will be rejected. Independent variable shows 68 percent variation in the dependent variable. It shows the expected sign means total production have positive impact on export volume. Likely results for other two sectors suggest that with high production we can increase our export volume.

Long Run

Equation: United

TABLE 19. Wald test.

\begin{tabular}{cccc}
\hline Test Statistic & Value & df & Probability \\
\hline F-Statistics & 4.627100 & $(5,20)$ & 0.0057 \\
\hline Chiq-square & 23.13550 & 5 & 0.0003 \\
\hline
\end{tabular}

9. Null Hypothesis Summary

TABLE 20. Null hypothesis test.

\begin{tabular}{ccc}
\hline Normalized Restriction (=) & Value & Std. Err \\
\hline C (4) & 0.060205 & 0.046079 \\
\hline C (6) & -0.072129 & 0.038489 \\
\hline C (7) & -0.057516 & 0.035365 \\
\hline C (8) & -0.017374 & 0.021072 \\
\hline C (9) & 0.022659 & 0.012197 \\
\hline
\end{tabular}

Production of Yarn impacts yarn exports in the long run. So the total production positively impacts all sectors of textile industry. It means with increasing of total production export volume will be increase. 


\section{CONCLUSION AND RECOMMENDATIONS}

Pakistan Text industry is export oriented and has an overwhelming impact on the economy. Textile industrial sector generates about $65 \%$ of total country's export: providing employment to $38 \%$ of total work force, and contributes $8.5 \%$ to GDP as per the Ministry of Textile figures. According to the figures the production of Textile industry are decreasing year by year. Unfortunately, since 2005 , globally cotton and textile community arc facing severe conditions despite of which part of the business they arc belonging. Pakistan's textile industry is also facing those conditions and some more severe local problems relating to the shortage of power and law and order problems. The shortage of power severely hinders the textile industry's ability to run on optimal capacity. In this study I have tried to find out the other variables which can affect export volume.

After analysis I came to the conclusion that which factors impact export volume of textile industry positively or negatively. There are some factors which do not affect export volume in any way like relative prices and exchange rate. During the last few years Pakistan's textile industry is going downward due of currency exchange rate fluctuation, energy crises and instability in Pakistan except last year in which cotton export volume has showed an improvement. Textile industry is the most important channel of foreign income generation and provision of employment. Lack of energy and political instability may have devastating impact on the economy. So, it is important to take necessary steps for political stability so that we can get currency stability and can make a strong market for our textile procluc1s. Textile industry should also search alternative ways to overcome energy crises. Because these problems are affecting our total textile production and have negative impact on our textile export volume.

This study examines different variables and their impact on export volume or textile industry in Pakistan. Towards the end I can say that some variable I have discussed in this study definitely have impact on export volume like total production, GDP and exchange rate volatility, some variables have no impact on export like relative prices and exchange rate. Relative prices arc foreign prices divided by domestic prices. It means if we increase or decrease domestic and foreign prices for cotton yarn and clothes it will not affect total export volume. However, there are other variables which are not included in this study also have impact on export volume, these include time trend, nature or trade agreement between domestic country and foreign country, nature of product, but these variables were not taken in the study due to unavailability of sources of data.

There is a special package for textile industry like other industries which includes relief in interest rates for loan for spinning sector and R\&D has been approved by the government to shore up the textile and clothing industry. But still there is need of other packages to boost up total production to maintain high export volume like relaxation in loans to the formers, workshops arranged to educate the formers etc. Highest priority has been given to the advancement of manufacturing industries as Pakistan's founding with major stress on Agro-Based Industries. Being one of the largest cotton producers in the world. Pakistan Textile Industry should make full use or its abundant resources which includes fertile land, labor and suitable environment etc.

As exchange rate volatility have a negative impact on our exports so initiative must be taken to stable and strong our currency as compare to other currencies. Furthermore, while analyzing the data I have seen great deal of variation in preparation of data, which give space for misrepresentation and misstatement or foci relating to textile industry. So, there is a strong need of further research in this area and I feel that my preliminary work substantially contributes to our understanding of those factors which affect our textile export. Moreover, I have only taken three sectors that are cotton yarns and cloths, there are other sectors which boost up our textile exports has equal impact and equal importance should be given to all sectors of textile industry.

\section{REFERENCES}

[1] Faruk. A, Cyplak \& Eray.Y, (2004)."Export supply and impart Demand Models for the Turkish Economy", Research Department Working Paper, Vol. 4, No. 9, pp. 1-29.

[2] Fayyaz. H. (2007) "Pakistan's Exports Demand: A Disaggregated Analysis" SBP Research Bulletin, Vol. 6, No. 2, pp.1-13.

[3] Iqbal. M \& Habib. A (2011). "Exchange Rate Volatility \& Macroeconomic Variables in Pakistan". Business Management Dynamics, Vol. 1, No. 2, pp. 11-22.

[4] Kenneth. R. H (1996). "The Textile Industry in Southeast Asia, 1400-1800". The Journal of the Economic and Social History of the Orient, Vol. 39, No. 2, pp. 87-135.

[5] Mariam. C. \& Cecilio. T. (2004). "Estimating the Export and Import Demand for Manufactured Goods; The Role of FDI". Review of World Economics, Vol. 140, No. 3, pp.347-375.

[6] Mark.S. (2004). "Impact of the exchange rate on export volumes". Reserve bank of Newzeland: Bulletin, Vol.67. No. 1. pp. 1-9.

[7] Md. Belayed. H (2006). "Export performance of Bangladesh's Fisheries Sector". The Journal of Developing Areas, Vol. 39, No. 2, pp. 63-77.

[8] Panos. K, Peter. B. \& Richard. G. (2000). "Estimation of export demand function for U.S. Wheat". Western Journal of Agricultural Economics, Vol. 3, No. 1, pp. 39-49.

[9] Piet. S. \& Rehman. U. (2003). "Exchange rate volatility and international trade: A general equilibrium analysis". European Economic Review, Vol. 47, No.1, pp. 429-441.

[10] Rana. E, Tasnim. K \& Furqan. M. (2010). "Export Potential of Cottage Industry: A Case Study of Sialkot (Pakistan)”. European Journal of Economics, Vol. 27, No. 1, pp. 158-164. 
[11] Sam. C \& Khair. U.Z. (2006). "Export Function Estimation for the Pakistan Carpet Industry". The Pakistan Development Review, Vol. 45 No. 4, pp. 1287-1297.

[12] Saten.K. (2011). "Estimating export demand equations in selected Asian countries". Journal of Chinese Economic and Foreign Trade Studies, Vol. 4, No. 1, pp.5-16.

[13] Usman. H, Khalid M. \& Azhar. A. (2005). "Estimation of Export Supply Function for Citrus fruits in Pakistan". The Pakistan Development Review, Vol. 44, No. 5, pp.659-672.

[14] Vladimir.B. (2003). "Determining Factors of Exports and Imports; A Synthesis of Explanatory Paradigms:" IIASA-ETI Occasional, Paper No. 11

[15] Saten.K. (2011). "Estimating export demand equation in selected Asian countries". Journal of Chinese Economic and Foreign Trade Studies, Vol. 4, No. 1, pp.5-16.

\section{AUTHOR PROFILE}

Dr. Usman Ghani is working as Assistant Professor in the Department of Mechanical Engineering UET Peshawar. Dr Ghani specialty is in the Manufacturing System Design and Planning and Technology Business Models. He is active member of British Engineering Council and Member of IMechE. 